\title{
PASAR DAN PEMASARAN
}

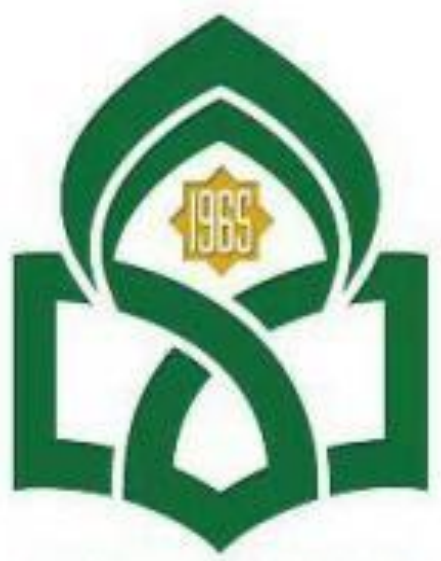

UNIVERSITAS ISLAM NEGERI

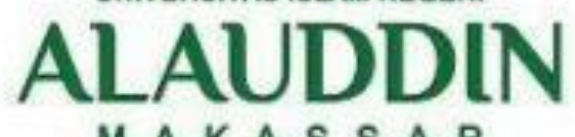

$M A K A$ S S A R

NAMA : ULFA RAMDHANI

NIM : 90500120099

PSY : C

PROGRAM STUDI PERBANKAN SYARIAH

FAKULTAS EKONOMI \& BISNIS ISLAM

UNIVERSITAS ISLAM NEGERI ALAUDDIN MAKASSAR

$2020 / 2021$ 


\section{KATA PENGANTAR}

Puji dan syukur saya panjatkan kehadirat Tuhan Yang Maha Esa karena berkat rahmat dan karunianyalah hingga makalah yang berjudul "PASAR DAN PEMASARAN" ini dapat kami selesaikan dengan cukup mudah dan sesuai dengan waktu yang telah di tentukan. Tanpa pertolongannya mungkin saya tidak bisa menyelesaikan makalah ini dengan tepat waktu. Saya mengucapkan terima kasih kepada Ibu Dra. Hj. Nuraeni Gani, MM. selaku Dosen Studi Kelayakan Bisnis Perbankan Syariah yang telah memberikan tugas makalah ini yang semoga nantinya dapat memberikan wawasan yang lebih luas kepada para pembaca. Saya menyadari bahwah makalah ini sangat banyak kekurangannya. Oleh karena itu, saya mengharapkan kritik dan saran yang dapat membangun makalh ini. Terima kasih.

Gowa, 27 November 2021

Penulis 


\section{DAFTAR ISI}

SUMBER DAYA MANUSIA

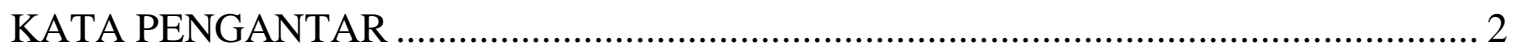

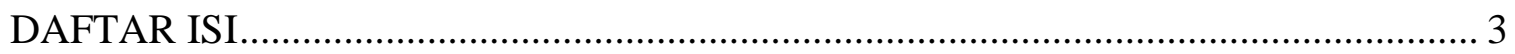

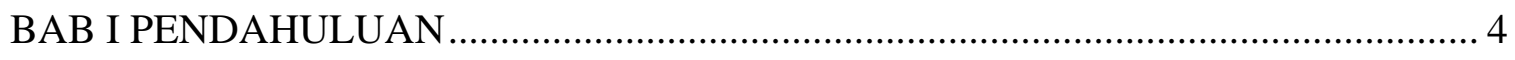

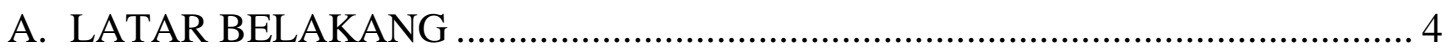

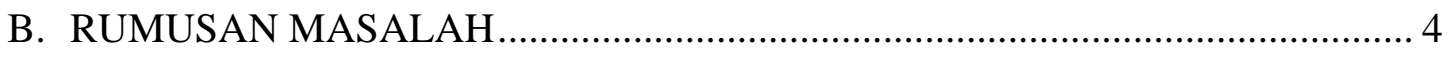

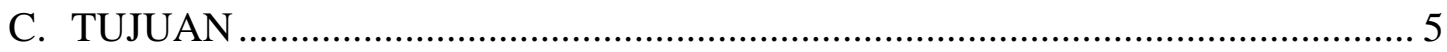

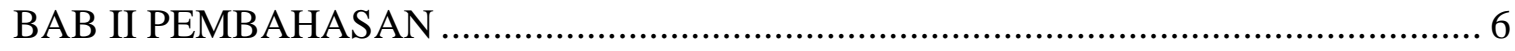

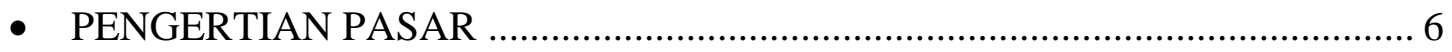

• JENIS JENIS SEGMENTASI PASAR ...................................................... 7

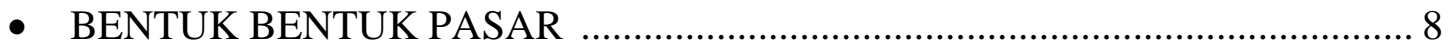

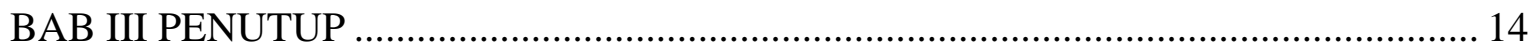

-KESIMPULAN .................................................................................. 14

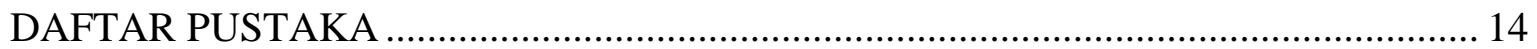




\section{BAB 1}

\section{PENDAHULUAN}

\section{A.LATAR BELAKANG}

Suatu perusahaan dalam menjalankan aktivitasnya wajib efisien menjalankan konsep pemasaran supaya laba yg dibutuhkan bisa terlaksana dengan baik. Ini mengindikasikan bahwa aktivitas pemasaran pada perusahaan harus dikoordinasi dan dikelola menggunakan cara yang labih baik.

Falsafah konsep pemasaran bertujuan buat menaruh kepuasan terhadap keinginan dan kebutuhan konsumen. Kegiatan perusahaan yang berdasar pada konseop pemasaran ini wajib diarahkan buat memenuhi tujuan perusahaan.Secara definitive bisa dikatakan bahwa konsep

pemasaran merupakan falsafah bisnis yang menyatakan bahwa pemuasan kebutuhan konsumen adalah syarat ekonomis dan social bagi kelangsungan hidup perusahaan

dari definisi tersebut, perusahaan mempunyai konsekuensi semua aktivitas perusahaan wajib diarahkan buat mengetahui kebutuhan konsumen dan mampu memberikan kepuasan supaya menerima keuntungan pada jangka panjang. Organisasi perusahaan yang menerapkan konsep pemasaran ini dianggap organisasi pemasaran.

Konsep pemasaran juga menyatakan bahwa kunci buat meraih tujuan organisasi merupakan sebagai lebih efektif daripada para pesaing pada memadukankegiatan pemasaran guna memutuskan dan memuaskan kebutuhan pasar sasaran. Konsep pemasaran ini bersandar dalam empat pilar, yaitu ' pasar sasaran, kebutuhan pelanggan, pemasaran terpadu dan profitabilitas.

Dewasa ini konsep pemasaran mengalami perkembangan yang semakin maju sejalan menggunakan majunya warga dan teknologi. Perusahaan tidak lagi berorientasi hanya dalam pembeli saja, akan namun berorientasi dalam masyarakat atau manusia. Konsep yang demikianlah yang dianggap menggunakan konsep pemasaran masyarakat.

\section{B,RUMUSAN MASALAH}

1. Bagaiman pengertian pasar? 
2. Bagaiman jenis jenis segmentasi pasar?

3. Bagaiman bentuk bentuk pasar ?

\section{C.TUJUAN}

1. untu mengertahui pengertian pasar

2. untuk mengetahui jenis jenis segmentasi pasar

3. untuk mengetahui bentuk-bentuk pasar 


\section{BAB II \\ PEMBAHASAN}

\section{A.PENGERTIAN PASAR}

Pasar secara generik diartikan menjadi tempat penjual menunjukkan barang atau jasa sesuai taksiran harga penjual dan pembeli menerima barang atau jasa sesuai menggunakan taksiran harga pembeli. Pengertian pasar pada ilmu ekonomi lebih konseptual, yakni bertemunya permintaan dan penawaran. Dengan demikian sebuah pasar tidak wajib dikaitkan menggunakan suatu tempat.

Pasar tradisional adalah tempat bertemunya penjual dan pembeli serta ditandai menggunakan adanya transaksi penjual dan pembeli secara pribadi, bangunan umumnya terdiri menurut kios-kios atau gerai, los, dan dasaran terbuka yang dibuka sang penjual juga suatu pengelola pasar. Seiring menggunakan perkembangan jaman, pasar mengalami perkembangan baik secara fisik (bangunan) dan non fisik (pelayanan). Pasar berkembang sebagai sebuah kebutuhan yang wajib dipenuhi lantaran faktor modernisasi. Istilah pasar tradisional dan pasar terkini pun ada kepermukaan. Keberadaan pasar yang kumuh, becek dan sempit mulai terlupakan menggunakan kehadiran pasar modern pada tengah - tengah masyarakat.

Pasar modern merupakan pasar yang dikelola sang manajemen modern, biasanya masih ada pada perkotaan, menjadi penyedia barang dan jasa menggunakan mutu dan pelayanan yang baik pada konsumen. Di pasar modern, penjual dan pembeli tidak bertransaksi secara pribadi melainkan pembeli melihat label harga yang tercantum pada barang (barcode), berada pada bangunan, dan pelayanannya dilakukan secara mandiri (swalayan) atau dilayani sang pramuniaga. Pasar modern diantaranya supermarket, mall, mini market, shopping centre, department store, dan sebagainya. Barang yang di jual mempunyai variasi jenis yang majemuk dan memiliki kualitas yang relatif lebih terjamin lantaran melalui penyeleksian terlebih dahulu secara ketat. Secara kuantitas, pasar modern biasanya memiliki barang persediaan pada gudang yang terukur. Dari segi harga, pasar modern mempunyai label harga yang pasti ( tercantum harga sebelum dan selesainya pajak). Pasar modern juga menaruh pelayanan yg baik menggunakan adanya indera pendingin udara. 


\section{B. JENIS JENIS SEGMENTASI PASAR}

Segmentasi pasar ini dilakukan tidak hanya oleh pemangku kepentingan UKM, tetapi juga oleh pemangku kepentingan perusahaan besar. Dengan ini, promosi produk atau jasa diperlukan mampu lebih paripurna sasaran sebagai akibatnya penjualan mampu meningkat.

Dalam hal ini, masih ada 6 jenis segmentasi pasar, yaitu :

\section{a) Segmentasi perilaku}

Segmentasi ini membagi konsumen dari pengetahuan, loyalitas, respon \& penggunaan konsumen terhadap produk atau jasa yang Anda tawarkan. Anda juga mampu membaginya dari seberapa besar manfaat yang diperoleh konsumen dari produk / jasa Anda. bila menjual kuas make-up, lakukan kenaikan pangkat online dalam tempat menjual make-up tersebut. Hal ini akan menaruh Anda peluang lebih besar menerima pelanggan dari pada menjualnya pada lapak alat make-up.

b) Segmentasi psikografis

Segmentasi ini membagi konsumen dari hal yang disukai, aktivitas yang dilakukan dan pendapat konsumen. Dengan kata lain, segmentasi ini berfokus dari segi aspek psikologis contohnya hobi dan minat. Menargetkan manajer dan karyawan kesekretariatan untuk dipromosikan ke penulis, penerbit, dan gerombolan perusahaan mempermudah penjualan buku catatan buatan tangan.

c) Segmentasi demografis

Strategi ini membagi konsumen dari ciri generik konsumen, misalnya: usia, gender, pekerjaan, pendidikan, pendapatan \& lainnya. Segmentasi ini sebenarnya relatif gampang dilakukan lantaran jumlah konsumen yang poly. Namun, juga relatif sulit karena memiliki pangsa pasar yang sangat besar. Sehingga membutuhkan bisnis yang lebih besar \& pembagian yang lebih rinci supaya menerima konsumen yang sangat sesuai.

d) Segmentasi geografis

Strategi ini membagi konsumen dari unit geografis yang berbeda, misalnya negara, provinsi, kabupaten/ kota, \& sebagainya. Dalam hal ini, kita sanggup menggunakan segmentasi 
demografis untuk menggabungkan segmentasi geografis. apabila Anda jual tunggangan beroda empat golf menggunakan harga yang relatif mahal, maka pangsa pasar yang sanggup Anda pilih merupakan perusahaan-perusahaan besar juga yang masih ada dalam Jakarta.

e) Segmentasi saat khusus

Segmentasi ini berfokus dalam pelaksanaan pemasaran dalam waktu-waktu tertentu. Misalnya, bila Anda berkecimpung dalam bisnis fotografi, Anda sanggup membuka booth foto dalam sekolah atau universitas tempat Anda mengadakan upacara kelulusan. apabila Anda menjual minuman, maka waktu tidak lagi penting bagi Anda lantaran Anda hanya perlu menunggu orang haus buat tiba ke loka Anda.

f) Segmentasi budaya

Setiap budaya mempunyai kepercayaan masing-masing. Mengetahui kepercayaan masingmasing budaya dan menggunakannya sebagai pendekatan pemasaran bisa menarik lebih banyak konsumen.

\section{C.BENTUK BENTUK PASAR}

\section{A.pasar persaingan sempurna}

Pasar persaingan sempurna bisa didefinisikan menjadi struktur pasar atau industri dimana masih ada banyak penjual dan pembeli. Dan setiap penjual ataupun pembeli tidak bisa mempengaruhi keadaan pada pasar.

\section{1)Ciri-Ciri Pasar Persaingan Sempurna}

a) . Setiap perusahaan adalah "pengambil harga" ialah suatu perusahaan yang terdapat di dalam pasar tidak bisa memilih atau merubah harga pasar. Adapun perusahaan di dalam pasar tidak akan mengakibatkan perubahan ke atas harga pasar yang berlaku. Harga barang pada pasar ditentukan oleh interaksi diantara keseluruhan produsen dan keseluruhan pembeli.

b) Setiap perusahaan mudah keluar atau masuk ialah sekiranya perusahaan mengalami kerugian, dan ingin meninggalkan industri tadi, langkah ini menggunakan mudah 
dilakukan.Sebaliknya jika terdapat pembuat yang ingin melakukan aktivitas diindustri tadi. penghasil tadi bisa menggunakan mudah melakukan kegiatan tersebut.

c) Setiap perusahaan membentuk barang yang sama atinya bahwa barang yang didapatkan banyak sekali perusahaan tidak gampang buat dibeda-bedakan. Pembeli tidak bisa membedakan yg mana didapatkan sang pembuat A atau B.

d) Banyak perusahaan dalam pasar ialah lantaran jumlah perusahan sangat banyak dan relatif kecil bila dibandingkan menggunakan jumlah produksi pada industri tersebut. Menyebabkan kenaikan atau penurunan harga, sedikitpun tidak mempengaruhi harga yang berlaku pada pasar tersebut.

e) Pembeli memiliki pengetahuan yang paripurna mengenai keadaan pada pasar ialah bahwa pembeli mengetahui taraf harga yang berlaku dan perubahan-perubahan ke atas harga tersebut. Sehingga pembuat tidak bisa menjual barangnya menggunakan harga yang lain lebih tinggi dan pada yang berlaku pada pasar.

2)Kelebihan Pasar PersainganSempurna

a) Karena biaya yang tidak terlalu tinggi,penjual bebas membuka maupun menutup usahanya.

b) Barang yang tersedia di pasar banyak.

c) Penjual dan pembeli mencapai kepuasanmaksimum

3)Kelemahan Pasar PersainganSempurna

a) Penjual tidak bisa memaksimalkan keuntungan Lantaran keuntungan di tentukan oleh pembeli.

b) Hanya terdapat pada syarat Perekonomian ideal.

c) Pasar persaingan sempurna tidak mendorong inovasi

d) Pasar persaingan paripurna adakalanya menyebabkan biaya social

e) Pasar persaingan paripurna membatasi pilihan konsumen

f) Biaya produksi pada pasar persaingan paripurna mungkin lebih tinggi

g) Distribusi pendapatan tidak selalu merata

4)Contoh pasar persaingan paripurna antara lain:

- Pasar SayurPasar sayur pula sanggup dibilang sebagai model pasar persaingan paripurna. Jumlah penjual sayur sangat banyak dan sama menggunakan jumlah pembelinya. Komoditas sayur pun mempunyai harga pasar sendiri yang tidak sanggup ditentukan baik 
sang penjual atau pun sang pembeli.Harga sayur memang dipengaruhi sang hubungan jumlah penawaran dan permintaan pasar.Barang yang dijual pun homogen berupa sayursayuran.Pembeli pun tidak akan membeli sayur dengan harga diatas harga pasar,sebaliknya penjual pula tidak akan menjual sayur menggunakan harga pada bawah harga pasar.

- Pasar Buah Sama seperti pasar sayur,pasar buah juga bisa dikategorikan sebagai contoh pasar pesaingan sempurna .Jumlah penjual buah dan pembeli buah memang sama- sama banyak dan bisa ditemui dimana-mana. Harga buah pun sudah dibentuk oleh prosedur pasar lewat kurva permintaan dan penawaran. Meski tidak bisa dibilang murni sebagai pasar persaingan sempurna,tetapi setidaknya prosedur dan struktur dalam pasar buah telah mendekati pasar persaingan sempurna.

- Pasar Modal Pasar modal termasuk pasar persaingan sempurna lantaran sesuai menggunakan karakteristik-cirinya. Secara generik peran pasar modal memang relatif penting buat perekonomian negara.Dalam bursa pengaruh, harga telah dipengaruhi sang sistem harga berupa permintaan dan penawaran saham dan instrumen pasar modal lainnya. Selain itu pemerintah tidak sanggup melakukan intervensi, begitu pula menggunakan penjual dan pembeli yang tidak sanggup mempengaruhi harga.

\section{B.Pasar persaingan tidak sempurna}

Pasar persaingan tidak sempurna merupakan kebalikan dari pasar persaingan sempurna yaitu pasar yang terdiri atas sedikit penjual dan banyak pembeli. Pada pasar ini penjual bisa memilih harga barang. Barang yang diperjual belikan jenisnya heterogen (berbagai jenis barang). Pasar persaingan tidak sempurna memiliki beberapa bentuk pasar.

\section{PasarMonopoli,}

pasar monopoli adalah suatu bentuk pasar yang hanya terdapat satu perusahaan saja atau bisa dianggap suatu pasar yang penjualnya hanya terdapat satu dan pembelinya banyak dan membentuk barang yg tidak memiliki pengganti. Keuntungan yang dinikmati sang perusahaan monopoli merupakan laba yg melebihi normal dan ini diperoleh lantaran masih ada kendala yang sangat andal yang dihadapi perusahaan - perusahaan lain buat memasuki industri tersebut. 


\section{Ciri karakteristik pasar monopoli}

- hanya Ada SatuProdusen, misalnya yg telah disebutkan pada atas, dalam pasar monopoli hanya terdapat satu produsen atau penjual. Dalam hal ini,maka harga akan ditentukan sang penghasil tanpa terpengaruh oleh konsumen. Dengan begitu, penghasil atau penjual memiliki hak pada memilih harga (price maker) dan memonopoli pasar. Tetapi, tentu saja produsen akan menentukan harga pada produk yang mereka jual sesuai dengan kualitasnya.

- Tidak memiliki barang pengganti, barang yang didapatkan perusahaan monopoli tidak bisa digantikan sang barang lain yang ada dipasar. Atau dengan kata lain tidak terdapat barang mirip., misalnya merupakan genre listrik yang asal berdasarkan PLN tidak bisa digantikan menggunakan lampu minyak, lantaran listrik bukan hanya dipakai buat menghidupkan lampu saja namun juga buat menghidupkan televisi, setrika, radiodll.

- Tidak bisa kemungkinan untuk masuk ke pada industry, maksudnya lantaran sifatnya monopoli maka pesaing tidak bisa masuk ke pada pasar tersebut lantaran barang yg didapatkan hanya dimiliki sang perusahaan tersebut saja dan selain itu umumnya dibatasi menggunakan undang - undang dan bersifat legal.Dapat mempengaruhiharga, lantaran perusahaan monopoli adalah satu - satunya penjual pada pasar maka penentuan harga bisa dikuasai sepenuhnya, menggunakan mengendalikan ke atas produksi dan jumlah barang yang ditawarkan perusahaan monopoli bisa memilih harga dalam taraf yg dikehendaki

- .Promosi iklan kurang diperlukan, umumnya perusahaan monopoli tidak perlu mempromosikan barangnya dengan iklan karena pembeli akan membeli barang kepada perusahaan tersebut lantaran tidak ada pilihan.

2.Faktor Penyebab Monopoli

- Penguasaan bahan mentah

- Penguasaan teknik produksi tertentu

- Pemberian hak istimewa berdasarkan pemerintah (contohnya hak paten)

- Adanya lisensi (anugerah biar pada perusahaan eksklusif yang ditunjuk)

- Memiliki modal yg besar (lantaran penggabungan perusahaan)

- Memiliki prestasi dan keahlian yang tidak dimiliki orang lain

- Adanya monopoli yang diperoleh secara alamiah 


\section{Kelebihan pasar monopoli}

- pembuat sanggup mempertahankan posisinya sebagai penguasa pasar monopoli, yakni menggunakan cara melakukan terus penemuan \& berkreasi terhadap produkdanpelayanannya

- Umumnya dalam pasar monopoli tidak terdapat persaingan yang tidak sehat lantaran pada hal ini pasar hanya dikuasai menggunakan satu produsen saja

- Adanya sistem hak cipta atau hak paten pada pasar monopoli pada suatu produk akan menciptakan perusahaan lain termotivasi pada membentuk produk baru yang sanggup bersaing dalam produk tersebut.

- Pasar monopoli yang dipunyai sang instansi pemerintah atau negara akan memudahkan dalam proses pemenuhan kebutuhan atau pada kepentingan masyarakatumum.

4.Kelemahan pasar monopoli

- Didalam monopoli pasar akan terjadinya pasar gelap dan transaksi ilegal karena dalam barang-barang atau produk tadi sulit dihasilkan atau harganya yang terlalu mahal.

- pembuat bisa semena-mena dalam konsumen lantaran kekuatannya mutlah, misalnya bisa memilih harga barang terlalumahal.-Konsumen pada pasar ini tidak berkeinginan secara penuh karena tidak terdapat pilihan barang alternatif

- .pembuat bisa melakukan eksploitasi lantaran ingin menerima banyak laba dalam produk mereka.

5.Ada beberapa cara pencegahan yang generik dipraktikkan buat mengatasi pengaruh negatif yg disebabkan sang monopoli, yaitu:

- Penarikan pajak

- Pengendalian harga

- Pemilikan pemerintah buat barang-barang penting atau yang menguasai hajat hayati orang banyak

- Regulasi menggunakan menciptakan undang-undang anti monopoli

- Pendirian perusahaan olehpemerintah.

6.Dampak negative adanya monopoli

- Timbulnya ketidakstabilanharga. -Kecilnya volume produksi menimbulkan adanya biaya sosial yaitu biaya yang ditanggung oleh masyarakat. 
- Adanya unsur ketidak adilan karena monopolis akan menekan biaya produksi serendahrendahnya dalam pasar faktor produksi dan menggunakan harga tinggi pada pasar barang

- Kepentingan umum banyak diabaikan, karena orientasi usahanya hanya berdasarkan atas laba rugi saja.

7.Contoh Pasar Monopoli Pasar monopoli bisa dibedakan kedalam 2 jenis, Antara lain menjadi berikut

* Pasar Monopoli Murni atau Pure Monopoly merupakan suatu bentuk pasar yang sanggup dibilang sangat berbahaya misalnya PLN, PT Kereta Api dnn PAM.

* Pasar Near Monopoly atau pasar yang mendekati monopoli merupakan suatu pasaryang masih ada dalam satu orang penghasil saja. Contohnya penjual bakso pada sebuah wilayah bisa dianggap menjadi monopoli murni pada tempat tadi. Tetapi, akan sebagai near monopoly apabila masih ada penghasil lain yang berjualan bakso yang serupa. 


\section{BAB III \\ PENUTUP}

\section{KESIMPULAN}

Pasar secara generik diartikan menjadi tempat penjual menunjukkan barang atau jasa sesuai taksiran harga penjual dan pembeli menerima barang atau jasa sesuai menggunakan taksiran harga pembeli. Pasar berkembang sebagai sebuah kebutuhan yang wajib dipenuhi lantaran faktor modernisasi. Istilah pasar tradisional dan pasar terkini pun ada kepermukaan. Pasar modern diantaranya supermarket, mall, mini market, shopping centre, department store, dan sebagainya.

Jenis jenis segmentasi pasar: Segmentasi perilaku, Segmentasi psikografis, Segmentasi demografis, Segmentasi saat khusus, Segmentasi budaya.

Pasar persaingan sempurna bisa didefinisikan menjadi struktur pasar atau industri dimana masih ada banyak penjual dan pembeli. Dan setiap penjual ataupun pembeli tidak bisa mempengaruhi keadaan pada pasar.

Pasar persaingan tidak sempurna merupakan kebalikan dari pasar persaingan sempurna yaitu pasar yang terdiri atas sedikit penjual dan banyak pembeli. Pada pasar ini penjual bisa memilih harga barang. Barang yang diperjual belikan jenisnya heterogen (berbagai jenis barang). Pasar persaingan tidak sempurna memiliki beberapa bentuk pasar.

\section{DAFTAR PUSTAKA}

Pandji ,Anoraga, Djoko Sudantoko. 2002. Koperasi, Kewirausahaan, dan Usaha Kecil Jakarta : Penerbit Rineka Cipta.

Suwarsono, Suad.2014.Studi Kelayakan Proyek Bisnis,Sekolah Tinggi Ilmu Manajemen YKPN, Yogyakarta

Ummul, fadilah. 9 Nov. 2021.Aspek Pasar Dan Pemasaran. 
